\title{
THEORETICAL CONSIDERATIONS ON THE INTRA-COMMUNITARY TRADE STATISTIC SYSTEM
}

\author{
Pravăț Ionela-Cristina, Assistant \\ UNIVERSITY OF BACĂU \\ Răileanu Adriana-Sofia, Teaching assistant \\ ECONOMIC SCIENCES ACADEMY BUCHAREST
}

\begin{abstract}
:
With the integration into the European Union, in Romania has also been implemented the Intrastate statistical system that is based on gathering information on intra-communitary acquisitions and deliveries directly from the economic agents involved in these activities.

In the present paper we briefly present a number of legislative issues regarding: the implementation of the Intrastate system in Romania, persons required to provide statistical data in this regard, the Intrastate Declaration and threshold values of intra-communitary trade under which economic operators are relieved to convey this statement.
\end{abstract}

After the adhesion to European Union, the statistic data collecting system concerning goods trade with other countries has two components:

- Statistic system Intrastate - intracommunitarian trade statistic system

- Statistic system Extrastate - extracommunitarian trade statistic system

Because, in the moment when Romania become a member state of the European Union and a component of the Unique Market, the Romanian merchants did not have any longer the obligation of filling in the customs declaration for the goods commercialized with other member states, the customs control on the commercial exchanges between Romania and other member states of the EU disappeared.

Therefore, in order to substitute the disappearance of this data source, the Intrastate statistic system was implemented, a system that supposes the collecting of the information straight from the economic operators from the EU countries that realize goods exchange with other EU member state.

At the level of European Union, the INTRASTATE statistic System was operational starting with the 1st of January 1993 and has on its basis a series of Settlements that are applied to all EU member states: The Council Settlement no. 638/2004 concerning trade statistics between EU member states and The Commission Settlement no. 1982/2004 concerning the implementation of Council Settlement no. 638/2004.

In Romania, Intrastate system is used starting with the 1 st of January 2007, the date of Romania's adhesion to European Unions. For this, The National Institute of Statistics elaborated The Completion Norms of the Intrastate Statistic Declaration, approved in 2007, for their appliance in 2008 [President's Order INS no. 748, published in Official Monitor no. 879/21.12.2007].

\section{Persons that provide Intrastate statistic data}

Are obliged to provide statistic data Intrastate the economic operators that fulfill simultaneously the following three conditions:

- they are registered with VAT purposes;

- they realize goods exchanges with other EU member states;

- the total yearly value of goods exchanges with other EU member states, meaning the total value of entries, respective of dispatching, surpasses the Intrastate value threshold established every year for the two categories of fluxes.

The main document throughout which the persons that fulfill the above mentioned conditions declare statistic data separately about entries (the fluxes of goods that arrive from other EU member states towards Romania) and dispatching (the fluxes of goods that exist from Romania towards other 
EU member states) is the Intrastate statistic Declaration.

In rapport with the moment when the value threshold for those two categories of fluxes is surpassed, there are two categories of operators:

- economic operators that in the previous year surpassed the value thresholds established for the current year will transmit the Intrastate declaration for all the months of the year;

- economic operators that surpass the value thresholds during the year will transmit the Intrastate declaration starting with the month when the value thresholds were surpassed.

For an operator that is currently provider of statistic data, the obligation of filling in the Intrastate declaration disappears in the moment when, after an entire year, this has not reached a cumulative level of intracommunitarian goods exchanges, superior to the effectual Intrastate threshold.

\section{The value Intrastate thresholds}

The statistic thresholds represent the value limits of intra-communitarian exchanges beyond which the economic operators are exonerated from transmitting the Intrastate declaration. These are separately established, and it can bear different values for intra-communitarian goods entries and dispatching and are yearly published in the Romania's Official Monitor, at the end of the anterior year to the one when the value thresholds are effectual.

The INTRASTATE value thresholds established by National Institute of Statistics for 2008 are the following: for intracommunitarian entries - $300.000 \mathrm{RON}$, and for intra-communitarian dispatching - 900.000 RON.

\section{Intrastate Declaration}

Intrastate declaration is always handed in until the 15th of the month that follows the reference one, on electronic support, at the National Institute of Statistics, by using two electronic manners of filling in and transmitting the information, respective the on-line and off-line Intrastate declaration.

As it may be seen from the table below, the Intrastate statistic declaration may be transmitted under two forms, the standard declaration and the extended declaration. Therefore, it is possible for an operator to hand in the standard declaration for a certain category of fluxes and the extended declaration for the other flux, if the fluxes are situated on different categories.

Table no.1. Example of statistic declaration according to annual value of intra-communitarian goods exchanges

\begin{tabular}{|c|c|c|}
\hline Declaration type & Entries & Dispatching \\
\hline $\begin{array}{c}\text { There is no obligation of } \\
\text { sending the Statistic declaration } \\
\text { Intrastate }\end{array}$ & $<\quad 300.000 \mathrm{RON}$ & $900.000 \mathrm{RON}$ \\
\hline $\begin{array}{l}\text { The standard Declaration - all } \\
\text { information are completed, less } \\
\text { the statistic value }\end{array}$ & $\begin{array}{l}\geq \quad 300.000 \mathrm{RON} \\
<10.000 .000 \mathrm{RON}\end{array}$ & $\begin{array}{l}\geq \quad 900.000 \mathrm{RON} \\
<20.000 .000 \mathrm{RON}\end{array}$ \\
\hline $\begin{array}{l}\text { The extended Declaration - } \\
\text { where all the information are } \\
\text { completed, including the } \\
\text { statistic value }\end{array}$ & $\geq 10.000 .000 \mathrm{RON}$ & $\geq 20.000 .000 \mathrm{RON}$ \\
\hline
\end{tabular}

The Interstate statistic Declaration does not have to he written down for the following cases [Economic Tribune Magazine, no.26/03.2008, Bucharest, p. 23]:
a) services trade;
b) goods in simple transit;
c) temporary goods movements;

d) goods movements for/after reparation and/or sustenance;

e) goods exchange with those territories of EU member states that do not belong to the statistic territory of EU member states;

f) exchanges of goods in the frame of triangular trade, in the situation when the 
goods no not enter on the Romanian territory from other EU member states or there are not sent from Romania towards other EU member state.

\section{References:}

[1] Hinkelmann E. (2001), Foreign Trade Dictionary, Teora, Bucharest;

[2] *** Economic Tribune Magazine no. 26/03.2008, Bucharest;

[3] *** Fiscal Code, completed and modified with Law no. 343/17.07.2006;

[4] *** Law no. 86/2006 concerning Customs Code of Romania, published in O.M. no. 350/2006;

[5] President's Order INS no. 748, published in Official Monitor no. 879/21.12.2007;

[6] www.intrastat.ro. 